\title{
Phenotypic and molecular diversity of litchi cultivars in Mauritius
}

\author{
Madhvee MADHOU ${ }^{1}$, Theeshan BAHORUN² ${ }^{2}$ José Ignacio HORMAZA ${ }^{3 *}$
}

${ }^{1}$ Agric. Res. Ext. Unit, St Jean Road, Quatre Bornes, Mauritius

2 Dep. Biosci., Univ. Mauritius, Reduit, Mauritius

3 Inst. Hortofrutic. Subtrop. Mediterr. "La Mayora", Univ. Málaga-Consejo Super. Investig. Cient. (IHSM-UMA-CSIC), Estac. Exp. "La Mayora", 29760 Algarrobo-Costa, Málaga, Spain ihormaza@eelm.csic.es
* Correspondence and reprints

Received 6 February 2009 Accepted 16 October 2009

Fruits, 2010, vol. 65, p. 141-152 (C) 2010 Cirad/EDP Sciences All rights reserved DOI: 10.1051/fruits/2010009 www.fruits-journal.org

RESUMEN ESPAÑOL, p. 152

\section{Phenotypic and molecular diversity of litchi cultivars in Mauritius.}

Abstract - Introduction. Litchi has gained considerable economic importance in Mauritius as it is highly prized on the local and export markets for its size, colour and flavour, although no characterisation work has been performed so far. Materials and methods. In order to optimise litchi germplasm management in Mauritius, we evaluated 34 litchi accessions from three different agroclimatic regions. Phenotypic and morphological characters, and microsatellite markers were studied. Results and discussion. Phenological observations conducted over four consecutive fruiting cycles (2003/2004 to 2006/2007) showed that accessions could be grouped into early- and late-flowering cultivars, which initiated floral panicles from June to July and July to August, respectively. The harvesting season of litchi lasted from mid-November to mid-January with early-maturing cultivars being ready for harvest in the first month of the season. Phenological characters and fruit characterisation showed that the newly-introduced cultivar 'Yook Ho Pow' had a high commercial potential. Molecular studies using twelve pairs of SSR primers showed that, despite phenotypic variations among 'Tai So' genotypes in different locations (such as percentage of chicken-tongued seeds and leaflet size), the SSR profiles of leaf samples from all the studied 'Tai So' accessions were identical, suggesting that phenotypic differences could probably be attributed to environmental conditions rather than to genetic variations. Molecular characterisation revealed different cases of synonymies and homonymies in the genotypes studied.

Mauritius / Sapindaceae / Litchi chinensis / agronomic characters / microsatellites / phenology / SSR

Diversité phénotypique et moléculaire des cultivars de litchi de l'île Maurice.

Résumé - Introduction. Le litchi a acquis une importance économique considérable à l'île Maurice car ce fruit est très prisé sur le marché local et d'exportation pour sa taille, sa couleur et sa saveur. Pourtant aucun travail de caractérisation de l'espèce Litchi chinensis n'a été réalisé jusqu'à présent sur l'île. Matériel et méthodes. Afin d'optimiser la gestion du matériel génétique du litchi à l'île Maurice, nous avons évalué 34 accessions de litchi réparties dans trois régions agroclimatiques. Les caractères phénotypiques et morphologiques des fruits, ainsi que les marqueurs microsatellites ont été étudiés. Résultats et discussion. Les observations phénologiques réalisées sur quatre cycles de fructification consécutifs (2003/2004 à 2006/2007) ont montré que les accessions pouvaient être regroupées en cultivars à floraisons précoces ou tardives, à partir de panicules floraux formés de juin à juillet et de juillet à août, respectivement. La saison de récolte du litchi a duré de la mi-novembre à mi-janvier, les variétés précoces ayant été récoltables dès le premier mois de la campagne. Les caractères phénologiques et la caractérisation des fruits a montré que le cultivar nouvellement introduit 'Yook Ho Pow' avait un fort potentiel commercial. Des études moléculaires utilisant douze paires d'amorces de RSS ont montré que, malgré les variations phénotypiques chez les génotypes de 'Tai So' dans différents environnements (tels que le pourcentage de noyaux 'langue de poulet' ou la taille du foliole), les profils de RSS des échantillons de feuilles de toutes les accessions de 'Tai So' étudiées étaient identiques ; cela suggèrerait que les différences phénotypiques observées pourraient être attribuables aux conditions environnementales plutôt qu'à des variations génétiques. La caractérisation moléculaire a révélé différents cas de synonymies et homonymies dans les génotypes étudiés.

Mauritius / Sapindaceae / Litchi chinensis / caractère agronomique / microsatellite / phénologie / RSS 


\section{Introduction}

The lychee or litchi (Litchi chinensis Sonn.), a member of the soapberry or Sapindaceae family together with other important tropical and subtropical fruit trees species, such as longan (Dimocarpus longan Lour.) and rambutan (Nephelium lappaceum L.), is native to southern China, northern Vietnam, and the Malay peninsula. During the 19th and 20th centuries its cultivation extended to other countries with tropical or subtropical climates [1]. Currently, about $95 \%$ of the world's litchi production takes place in Southeast Asia with 2 Mt, with the main producers being China, Vietnam, Thailand, India, Bangladesh and Nepal [2].

The litchi was introduced into Mauritius in 1763 [3] and has gained considerable economic importance in this country as it is highly prized on the local and export markets for its size, colour and flavour. In Mauritius, litchi trees are grown in commercial orchards (10000 trees covering 55 ha) and in backyards (24000 trees) [4]. The most commonly locally grown cultivar is 'Tai So', whereas 'Calcuttia Late' and 'Hong Kong' are also grown on a very limited scale. A number of cultivars ('Bosworth 3', 'Bengal', 'Brewster', 'Heiye', 'Heong Lai', 'Huaizhi', 'Jensen', 'Kwai May Pink', 'Salathiel', 'Wai Chee', 'Yook Ho Pow' and 'Yuan Zhi') have been introduced from Australia and China in the last 20 years but limited data are available on their performance under local conditions. Cultivars with high percentages of aborted (chicken-tongued) seeds are particularly sought after as fruits with small seeds have higher consumer appeal. Local stakeholders of the litchi industry often claim that even within the 'Tai So' cultivar some trees consistently produce higher percentages of chicken-tongued seeds. It is still to be determined whether this phenomenon is attributed to environmental conditions or to genetic variation.

The identification of litchi cultivars in Mauritius is based solely on some fruit and leaf characters. Yet it is known that phenotypic traits can be influenced by environmental conditions [5] and are not reliable indicators of cultivar identity. Hence, along with morphological characterisation, molecular studies are essential to confirm the identity of litchi accessions for optimum germplasm management and establishment of appropriate breeding programmes. Microsatellites or simple sequence repeats (SSRs) can be considered as the molecular markers of choice for genotype identification due to their high polymorphism and reproducibility [6]. Microsatellites are tandem repetitions of 1-6 bp nucleotide motifs found in all genomes analysed to date and they have been successfully applied to differentiate litchi cultivars; a high proportion of them are also transferable to longan, a related species in the Sapindaceae [7, 8].

In order to optimise litchi production in Mauritius, our aims in this work were to identify germplasm of commercial interest, mainly with early maturation and good fruit quality, to evaluate the relationship between genetic variation and the percentage of chicken-tongued seeds among 'Tai So' accessions, and to clarify cases of homonymies and/or synonymies using microsatellites.

\section{Materials and methods}

\subsection{Litchi accessions}

Thirty-four litchi accessions from three different agroclimatic zones of Mauritius (Labourdonnais, Réduit and Paillotte) were studied. A local longan accession was also used as an outgroup for the molecular analysis (table I). Labourdonnais is a drier and warmer region than the two other sites (table II) but the orchards were irrigated so that water deficiency did not influence the performance of the accessions.

\subsection{Phenological observations and morphological analyses}

Phenological observations (floral initiation and harvest) and fruit characters were studied during four consecutive fruiting cycles (2003/2004 to $2006 / 2007)$. 
Table I.

Passport information for 34 local litchi and 1 longan accessions collected in Mauritius.

\begin{tabular}{|c|c|c|c|}
\hline Cultivar & Accession reference number & Origin in Mauritius & Reported source of origin \\
\hline Bengal & 5 & Paillotte & Australia \\
\hline Bengal & 14 & Réduit & Australia \\
\hline Bengal & 19 & Labourdonnais & Australia \\
\hline Bosworth 3 & 8 & Paillotte & Australia \\
\hline Bosworth 3 & 10 & Réduit & Australia \\
\hline Bosworth 3 & 32 & Réduit & Australia \\
\hline Brewster & 29 & Réduit & Australia \\
\hline Calcuttia Late & 9 & Paillotte & India \\
\hline Calcuttia Late & 18 & Paillotte & India \\
\hline Casino & 7 & Paillotte & Australia \\
\hline Casino & 31 & Réduit & Australia \\
\hline Heiye & 23 & Réduit & China \\
\hline Heiye & 24 & Réduit & China \\
\hline Heong Lai & 30 & Réduit & Australia \\
\hline Hong Kong & 21 & Paillotte & Australia \\
\hline Huaizhi & 34 & Réduit & China \\
\hline Jensen & 33 & Réduit & Australia \\
\hline Kwai May Pink & 25 & Réduit & Australia \\
\hline Salathiel & 27 & Réduit & Australia \\
\hline Tai So & 1 & Labourdonnais & China \\
\hline Tai So & 3 & Labourdonnais & China \\
\hline Tai So & 4 & Labourdonnais & China \\
\hline Tai So & 6 & Paillotte & China \\
\hline Tai So & 11 & Paillotte & China \\
\hline Tai So & 12 & Labourdonnais & China \\
\hline Tai So & 13 & Réduit & China \\
\hline Tai So & 16 & Paillotte & China \\
\hline Tai So & 17 & Réduit & China \\
\hline Tai So & 20 & Réduit & China \\
\hline Wai Chee & 28 & Réduit & Australia \\
\hline Yook Ho Pow & 2 & Labourdonnais & Australia \\
\hline Yook Ho Pow & 15 & Réduit & Australia \\
\hline Yook Ho Pow & 22 & Paillotte & Australia \\
\hline Yuan Zhi & 26 & Réduit & China \\
\hline Longan & 35 & Réduit & Unknown \\
\hline
\end{tabular}

\subsubsection{Period of floral initiation}

Daily temperature data were obtained from the Mauritius Meteorological Services stations in the zones where the study was conducted and the date at which minimum temperature stabilised below $20{ }^{\circ} \mathrm{C}$ was recorded. The date of first floral panicle emergence (panicle about $1 \mathrm{~cm}$ long) was also recorded. The number of weeks from the temperature drop to first floral panicle emergence (floral initiation) was then computed for each cultivar.

\subsubsection{Leaf characterisation}

Thirty mature leaves were evenly collected from each tree. The leaves were characterised according to number and arrangement of leaflets, colour of leaflets (according to 
Table II.

Normal rainfall, temperature and sunshine hours (1971-2000) for the three sites considered for studying litchi accessions in Mauritius.

\begin{tabular}{|c|c|c|c|c|c|}
\hline \multirow[t]{2}{*}{ Site } & \multirow{2}{*}{$\begin{array}{l}\text { Altitude } \\
\text { (asl) } \\
\text { (m) }\end{array}$} & \multirow[t]{2}{*}{$\begin{array}{l}\text { Yearly number } \\
\text { of sunshine hours }\end{array}$} & \multicolumn{2}{|c|}{$\begin{array}{l}\text { Mean monthly temperature } \\
\text { ( } \mathrm{C})\end{array}$} & \multirow[t]{2}{*}{$\begin{array}{l}\text { Mean annual rainfall } \\
(\mathrm{mm})\end{array}$} \\
\hline & & & Minimum & Maximum & \\
\hline Labourdonnais & 50 & 3074 & 19 & 28 & 1288 \\
\hline Réduit & 250 & 2670 & 18 & 26 & 1582 \\
\hline Paillotte & 350 & 2658 & 17 & 25 & 2039 \\
\hline
\end{tabular}

the Royal Horticultural Society colour chart), length of rachis and petiole, and shape of leaflets. Leaf morphology was described according to the litchi descriptors published by the IPGRI [9].

\subsubsection{Harvesting period and fruit characterisation}

One hundred uniformly distributed fruits were harvested from each tree when fully mature. Dates of harvest were recorded for the studied accessions during the four years of study. Fruits were weighed and the length and diameter of each fruit were recorded by using a calliper. Both the outer and inner skin colour of the harvested fruits were described at harvest according to the Royal Horticultural Society (RHS) colour chart. The fruit texture was described as being either smooth or prickly. The shapes were classified as being rounded or oval.

\subsubsection{Seed characteristics}

The seeds of the 100 harvested fruits were characterised according to length and diameter (using a calliper), colour (RHS colour chart), and weight, and they were classified as being either normal or chicken-tongued. The [pulp:seed] ratio of the harvested samples as well as the percentage of chickentongued seeds for each tree were also computed.

\subsubsection{Statistical analyses}

Analysis of variance was performed using SPSS 12.0 statistical software (SPSS Inc., Chicago, USA) to find significant differences $(p=0.05)$ among fruit and leaf traits of the studied cultivars.

\subsection{Genetic characterisation}

Genomic DNA was extracted from fresh and young leaves following the method described by Viruel and Hormaza [7].

\subsubsection{SSR analysis}

Twelve litchi SSRs were used for SSR fingerprinting [7]. Forward primers were labelled with WellRed fluorescent dyes (Proligo, Paris, France) on the 5' end. Fifteen $\mu \mathrm{L}$ of reaction solution containing $16 \mathrm{mM} \quad\left(\mathrm{NH}_{4}\right)_{2} \mathrm{SO}_{4}$, $67 \mathrm{mM}$ Tris- $\mathrm{HCl} \mathrm{pH} 8.8,0.01 \%$ Tween20, $2 \mathrm{mM} \mathrm{MgCl}_{2}, 0.1 \mathrm{mM}$ of each dNTP, $0.4 \mu \mathrm{M}$ of each primer, $25 \mathrm{ng}$ genomic DNA and 0.5 units of BioTaq ${ }^{\mathrm{TM}}$ DNA polymerase (Bioline, London, UK) were used for amplification in an I-cycler (Bio-Rad Laboratories, Hercules, CA, USA) thermocycler using the following temperature profile: an initial step of $1 \mathrm{~min}$ at $94^{\circ} \mathrm{C}, 35$ cycles of $30 \mathrm{~s}$ at $94^{\circ} \mathrm{C}$, $30 \mathrm{~s}$ at $45^{\circ} \mathrm{C}$ to $50{ }^{\circ} \mathrm{C}$ and $1 \mathrm{~min}$ at $72{ }^{\circ} \mathrm{C}$, and a final step of 5 min at $72^{\circ} \mathrm{C}$. PCR products were analysed by capillary electrophoresis in a $\mathrm{CEQ}^{\mathrm{TM}} 8000$ capillary DNA analysis system (Beckman Coulter, Fullerton, CA, USA). Each sample was run twice to guarantee reproducibility of results and DNA from the same 'Tai So' accession was used as a control in each run to ensure size accuracy and to minimise run-to-run variation.

Allele size determination and the total number of alleles were determined for each 
SSR locus. Putative alleles were indicated by the estimated size in bp. Genetic diversity was estimated in the single locus microsatellites with the program Arlequin version 3.01 using the following statistics: number of alleles per locus (A), observed heterozygosity (Ho) calculated as the number of heterozygous genotypes over the total number of genotypes analysed for each locus, and expected heterozygosity $\left(\mathrm{He}=1-\sum p_{i}^{2}\right.$ where $p_{i}$ is the frequency of the ith allele).

\subsubsection{Genetic diversity}

Genetic relationships among the genotypes studied were calculated using UPGMA cluster analysis of the similarity matrix obtained from the proportion of shared alleles from the single locus SSRs [10]. The cophenetic coefficient was computed for the dendrogram after the construction of a cophenetic matrix to measure the goodness of fit between the original similarity matrix and the dendrogram. All these analyses were computed with the program NTSYSpc 2.11 (Exeter Software, Stauket, NY, USA). Bootstrap support values were obtained from 2000 replicates using the program Treecon 1.3b [11]

\section{Results and discussion}

Since the accessions 'Heong Lai', 'Jensen', 'Kwai May Pink', 'Salathiel', 'Wai Chee' and 'Yuan Zhi' had not yet reached the fruit bearing stage during this study no flower phenological or fruit data are available yet for these cultivars.

\subsection{Leaf characteristics}

Leaf characteristics from accessions of the same cultivar did not vary much from each other, so average data are presented for each cultivar (table III). As some variations were recorded between the 'Tai So' leaves from Labourdonnais and the other locations, results of the 'Tai So' accessions from Labourdonnais are presented separately from the other 'Tai So' accessions.

Major differences among cultivars were noted in leaflet size and number of leaflets. 'Bosworth 3', 'Heiye', 'Heong Lai', 'Hong
Kong', 'Huaizhi', 'Jensen', 'Salathiel', 'Wai Chee' and 'Yuan Zhi' had smaller leaflets (less than $10 \mathrm{~cm}$ long and less than $3.5 \mathrm{~cm}$ wide) than other cultivars. Most cultivars had an average of six leaflets per compound leaf except for 'Wai Chee' and 'Yuan Zhi', which had four leaflets per leaf in general. It was also noted that the 'Tai So' leaflets from Labourdonnais were significantly larger (13.4 $\mathrm{cm}$ long and $3.8 \mathrm{~cm}$ wide) than leaflets from 'Tai So' trees from other regions (11.8 cm long and $2.6 \mathrm{~cm}$ wide). These variations could be attributed to environmental differences between Labourdonnais and the other two regions (table II); it has previously been reported that variations in environmental conditions can influence morphological traits among accessions of the same genotype [5]. An alternative explanation for this variation could be genetic differences among the accessions; however, the use of molecular markers in this study did not reveal any genetic variation among the studied 'Tai So' accessions (figure 1).

\subsection{Flowering behaviour of studied cultivars}

Both the exposure time (number of weeks after minimum temperature stabilised below $20{ }^{\circ} \mathrm{C}$ ) to low temperature prior to floral initiation and the period of floral initiation were recorded (table IV). Floral initiation of the cultivars occurred at different periods following the minimal temperature drop below $20{ }^{\circ} \mathrm{C}$. This is attributed to the different low temperature requirements of the cultivars for successful floral induction. 'Tai So' and 'Yook Ho Pow' had the lowest requirements ( 7 to 11 weeks); the other cultivars required 9 to 13 weeks. Consequently, 'Tai So' and 'Yook Ho Pow' started to initiate floral panicles earlier (mid-June) than the other cultivars (late June onwards). Other research studies have also reported that litchi cultivars differ in their chilling requirements prior to flowering [12-15]. In Thailand, litchi cultivars are subdivided into two groups: lowland cultivars, which do not require a long period of cool temperature to flower, and upland cultivars, which need longer periods of cool temperature [13]. Similarly, cultivars in China are subdivided into 


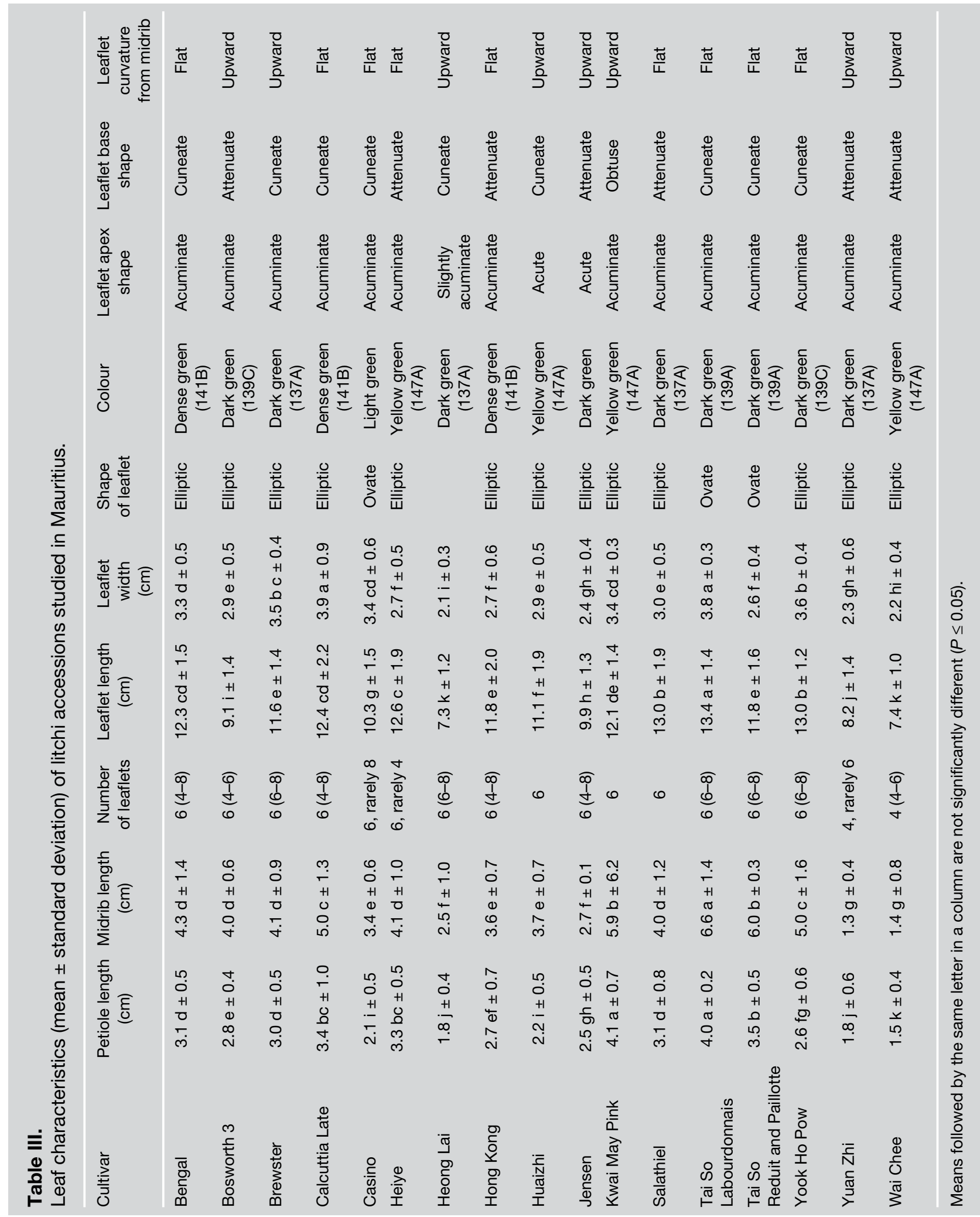




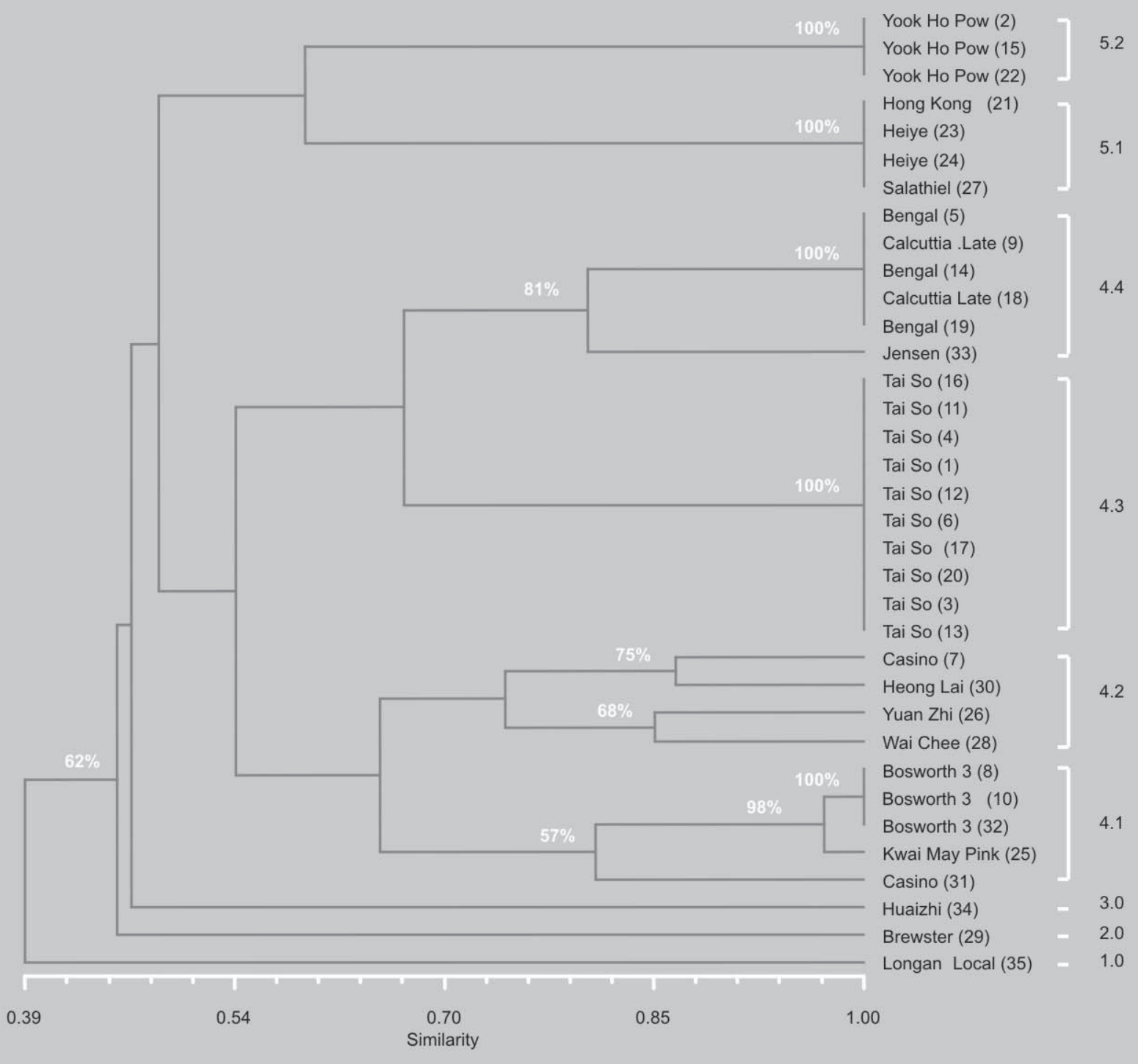

two ecological groups: 'cultivars of high chilling requirements' and 'cultivars of low chilling requirements', based on the quantitative nature of temperature requirements for successful floral induction [15].

Although this study was conducted under field conditions with wide temperature fluctuations, the exposure time (7 to 13 weeks) to low temperature required by the litchi cultivars were quite close to findings made by other authors under glasshouse conditions. Thus, in a series of glasshouse experiments with different cultivars, Menzel and
Simpson found that panicle emergence occurred from 6 to 10 weeks [16] , whereas O'Hare observed floral panicle emergence in 'Tai So' 6 to 7 weeks after trees were exposed to $18{ }^{\circ} \mathrm{C} / 13{ }^{\circ} \mathrm{C}$ day/night temperatures [17].

\subsection{Fruit maturity}

During the study period, the harvesting season lasted from mid-November to mid-January (table $I V)$. Two groups of cultivars could be distinguished based on harvesting

\section{Figure 1.}

Dendrogram of 34 litchi and 1 longan accessions generated by UPGMA analysis using Nei and Li similarity coefficient after amplification with 12 pairs of SSR primers. Bootstrap values out of 2000 replicates are shown if $50 \%$ or higher. Numbers in parenthesis indicate the accession reference numbers as presented in table 1 . 


\section{Madhou et al.}

Table IV.

Period of floral initiation and fruit maturation of litchi accessions studied in Mauritius.

\begin{tabular}{lccc}
\hline Cultivar & $\begin{array}{c}\text { Exposure time } \\
\text { (weeks) }\end{array}$ & Period of floral initiation & Harvesting period \\
\hline Bengal & $9-13$ & Mid-July to late August & Late December to mid-January \\
Bosworth 3 & $9-10$ & Late June to early July & Mid-July to mid-August \\
Brewster & $10-11$ & Mid-July to late August & Mid-December to early January \\
Calcuttia Late & $9-13$ & Mid-July to late July & Late December to mid-January \\
Casino & $10-12$ & Mid-July to mid-August & Mid-January \\
Heiye & $9-12$ & Mid-July to mid-August & Mid-December to mid-January \\
Hong Kong & $9-11$ & Late June to early July & Late December to mid-January \\
Huaizhi & $9-10$ & Mid-June to mid-July & Late December \\
Yook Ho Pow & $7-9$ & Mid-June to early August & Mid-November to mid-December \\
Tai So & $7-11$ & Mid-November to early January
\end{tabular}

periods. 'Yook Ho Pow' and 'Tai So' were the earliest-maturing cultivars with harvest beginning in mid-November, while all the other cultivars were late-maturing and were harvested from mid-December to late January. It was also observed that the cultivars 'Yook Ho Pow' and 'Tai So' were harvested earlier in Labourdonnais, where the temperature is also warmer (table II). Other litchi researchers have found that warmer conditions can lead to faster panicle and flower development [12] and fruit development and maturation [18]. The export market for Mauritian litchi is lucrative and the fruit reaches a premium price in Europe during the first weeks of November, before the large production volumes from Madagascar and South Africa enter the market. Thus, the marketing strategy for Mauritius will have to make the most of the small window of opportunity at the start of the season. The data showed that the cultivars 'Yook Ho Pow' and 'Tai So' have the potential to reach the market on time and fetch a high price. It would be of interest to grow these two early cultivars on warm sites to increase the volume of early production. On the other hand, growing late cultivars on cooler sites could have the advantage of extending the harvesting season and supplying the domestic market over a longer time.

\subsection{Fruit and seed characterisation}

Since fruit and seed traits from accessions of the same cultivar did not vary significantly from each other, average data are presented for each cultivar (tables $V, V I$ ). Nevertheless, since there were wide variations for seed traits between 'Tai So' accessions from Labourdonnais and those from the Paillotte and Reduit regions, data for 'Tai So' accessions from Labourdonnais are presented separately (table VI).

A wide variation in percentage of chicken-tongued seeds and pulp to seed ratio was recorded among accessions (table VI). Low percentages of chickentongued seeds (less than 5\%) and low pulp to seed ratios (less than 10) were recorded for the cultivars 'Bengal', 'Brewster', 'Calcuttia Late', 'Casino', 'Heiye', 'Hong Kong' and 'Huaizhi'. The 'Yook Ho Pow' accessions showed the highest percentage of chickentongued seeds $[(78.2 \pm 2.5) \%]$ and pulp to seed ratio $(16.1 \pm 3.3)$. It was also observed that the 'Tai So' trees from Labourdonnais had higher levels of fruits with chickentongued seeds $[(69.2 \pm 7.7) \%$ ] than 'Tai So' trees from the other sites $[(41.3 \pm 6.2) \%]$. The high percentage of chicken-tongued seeds of 'Tai So' in Labourdonnais is of commercial importance, thereby justifying the need to study the cause of this variation. High degrees of seed abortion have been associated with genetic diversity by some authors. For example, some cultivars such as 'Luhebao' [19], 'Nuomici' and 'Guiwei' [20], 'No Mai Chee', 'Kwai May' and 'Fay Zee Siu' [21] tend to show particularly high degrees of seed abortion. This characteristic has been attributed to the different levels, ratios 


\section{Table V.}

Fruit morphological characteristics of litchi accessions (mean \pm standard deviation) studied in Mauritius.

\begin{tabular}{|c|c|c|c|c|c|c|c|}
\hline \multirow[t]{2}{*}{ Cultivar } & \multirow{2}{*}{$\begin{array}{l}\text { Weight } \\
\text { (g) }\end{array}$} & \multicolumn{2}{|c|}{ Size $(\mathrm{mm})$} & \multirow[t]{2}{*}{ Shape } & \multirow[t]{2}{*}{ Texture } & \multicolumn{2}{|l|}{ Skin colour } \\
\hline & & Length & Diameter & & & Outer & Inner \\
\hline Bengal & $20.5 b \pm 1.8$ & $38.4 \mathrm{a} \pm 3.2$ & $31.1 \mathrm{a} \pm 2.5$ & Oval and pointed at both ends & Very Prickly & Deep red $(46 A)$ & Pink \\
\hline Bosworth 3 & $17.2 f \pm 1.3$ & $31.3 d \pm 1.6$ & $30.1 \mathrm{bc} \pm 2.0$ & Rounded & Prickly & Yellow green (150B) & White \\
\hline Brewster & 18.2 e \pm 1.1 & $33.8 c \pm 1.7$ & $29.4 c \pm 1.4$ & Rounded to oval & Prickly & Bright red (45A) & White \\
\hline Calcuttia Late & $20 c \pm 1.4$ & $39.5 a \pm 2.1$ & $31.2 \mathrm{a} \pm 1.8$ & Oval and pointed at both ends & Very Prickly & Deep red $(46 A)$ & Pink \\
\hline Casino & $14.0 \mathrm{~h} \pm 1.7$ & $27.1 \mathrm{f} \pm 1.6$ & $25.8 \mathrm{e} \pm 2.0$ & Rounded & Prickly & $\operatorname{Red}(43 A)$ & White \\
\hline Heiye & $16.1 \mathrm{~g} \pm 1.3$ & $27.8 f \pm 3.2$ & $25.4 \mathrm{e} \pm 2.8$ & Rounded & Prickly & Orange red (46B) & White \\
\hline Hong Kong & $16.5 \mathrm{~g} \pm 1.2$ & $29.2 \mathrm{e} \pm 1.8$ & $27.9 d \pm 2.1$ & Rounded & Prickly & Orange red (46B) & White \\
\hline Huaizhi & $17.4 f \pm 1.2$ & $30.9 d \pm 1.2$ & $27.8 d \pm 1.1$ & Rounded & Prickly & $\operatorname{Red}(43 \mathrm{~A})$ & White \\
\hline Tai So & $19.2 d \pm 1.4$ & $34.5 c \pm 2.8$ & $30.8 \mathrm{~b} \pm 1.7$ & Oval & Prickly & $\operatorname{Red}(43 \mathrm{~A})$ & White \\
\hline Yook Ho Pow & $21.2 a \pm 1.6$ & $36.4 b \pm 3.0$ & $31.6 \mathrm{a} \pm 1.9$ & Oval and pointed at both ends & Prickly & Green (149A) & Pink \\
\hline
\end{tabular}

Colour codes are from the Royal Horticultural Society Colour Chart.

Means followed by the same letter in a column are not significantly different $(P \leq 0.05)$.

Table VI.

Seed characteristics (mean \pm standard deviation) of litchi accessions studied in Mauritius.

\begin{tabular}{|c|c|c|c|c|c|c|}
\hline \multirow[t]{2}{*}{ Cultivar } & \multicolumn{2}{|c|}{ Normal seeds } & \multicolumn{3}{|c|}{ Chicken-tongued seeds } & \multirow{2}{*}{$\begin{array}{c}\text { Pulp } \\
\text { to seed ratio }\end{array}$} \\
\hline & $\begin{array}{l}\text { Length } \\
(\mathrm{mm})\end{array}$ & $\begin{array}{l}\text { Diameter } \\
\quad(\mathrm{mm})\end{array}$ & $\begin{array}{l}\text { Length } \\
(\mathrm{mm})\end{array}$ & $\begin{array}{l}\text { Diameter } \\
\quad(\mathrm{mm})\end{array}$ & Percentage & \\
\hline Bengal & $29.4 \mathrm{a} \pm 2.0$ & $13.8 \mathrm{bc} \pm 1.0$ & $24.9 \mathrm{a} \pm 1.4$ & $9.2 \mathrm{a} \pm 1.2$ & $3.0 \pm 1.0$ & $4.4 \mathrm{~b} \pm 0.7$ \\
\hline Bosworth 3 & $23.8 b c \pm 3.5$ & $13.5 c \pm 1.6$ & $14.0 \mathrm{~cd} \pm 2.1$ & $7.2 \mathrm{~d} \pm 1.2$ & $48.1 \pm 9.3$ & $4.1 \mathrm{~b} \pm 0.4$ \\
\hline Brewster & $24.7 b \pm 1.5$ & $15.3 \mathrm{a} \pm 1.7$ & Nil & Nil & Nil & $4.2 b \pm 0.3$ \\
\hline Calcuttia Late & $29.9 \mathrm{a} \pm 1.7$ & $14.1 \mathrm{~b} \pm 1.2$ & $22.9 \mathrm{a} \pm 2.9$ & $6.5 \mathrm{e} \pm 1.4$ & $2.1 \pm 0.6$ & $4.1 \mathrm{~b} \pm 0.5$ \\
\hline Casino & $18.6 f \pm 1.8$ & $13.9 \mathrm{bc} \pm 1.2$ & $12.04 \mathrm{e} \pm 1.2$ & $8.7 b \pm 1.2$ & $2.3 \pm 0.6$ & $4.2 b \pm 0.1$ \\
\hline Heiye & $19.7 \mathrm{e} \pm 1.2$ & $12.8 \mathrm{~d} \pm 1.1$ & $19.2 b \pm 1.5$ & $6.9 \mathrm{~d} \pm 1.6$ & $3.0 \pm 1.2$ & $5.8 b \pm 0.1$ \\
\hline Hong Kong & 19.5 ef \pm 1.5 & $13.1 \mathrm{~d} \pm 1.4$ & $15.2 \mathrm{c} \pm 1.0$ & $7.7 c \pm 0.8$ & $2.3 \pm 0.6$ & $5.2 b \pm 1.3$ \\
\hline Huaizhi & $21.8 d \pm 0.8$ & $11.3 e \pm 0.8$ & Nil & Nil & Nil & $3.8 b \pm 0.3$ \\
\hline Tai So (Labourdonnais) & $23.6 c \pm 1.9$ & $13.6 c \pm 1.9$ & $19.2 b \pm 2.0$ & $8.5 b \pm 2.7$ & $69.2 \pm 7.7$ & $5.5 b \pm 2.2$ \\
\hline Tai So (Paillotte \& Réduit)| & $23.2 c \pm 2.1$ & $13.9 b c \pm 2.0$ & $19.3 b \pm 2.1$ & $8.8 a b \pm 1.3$ & $41.3 \pm 6.2$ & $6.1 b \pm 2.3$ \\
\hline Yook Ho Pow & $20.9 d \pm 2.2$ & $10.8 \mathrm{e} \pm 1.4$ & $13.2 \mathrm{de} \pm 1.5$ & $8.4 b \pm 1.5$ & $78.2 \pm 2.5$ & $16.1 \mathrm{a} \pm 3.3$ \\
\hline
\end{tabular}

Means followed by the same letter in a column are not significantly different $(P \leq 0.05)$

No statistical test was conducted on percentage of chicken-tongued seeds as there were only four readings (one reading per year) for each cultivar for this parameter. 
Table VII.

Variability parameters for 12 SSR studied in 34 litchi accessions analysed in Mauritius.

\begin{tabular}{|c|c|c|c|c|c|}
\hline SSR & $\begin{array}{c}\text { Annealing } T_{a} \\
\left({ }^{\circ} \mathrm{C}\right)\end{array}$ & Size range & $\begin{array}{l}\text { Number of alleles } \\
\text { (A) }\end{array}$ & $\begin{array}{c}\text { Observed heterozygosity } \\
\text { (Ho) }\end{array}$ & $\begin{array}{l}\text { Expected heterozygosity } \\
\qquad(\mathrm{He})\end{array}$ \\
\hline LMLY $1^{1}$ & 50 & $154-183$ & 8 & NA & NA \\
\hline LMLY 2 & 45 & $178-190$ & 4 & 0.58 & 0.91 \\
\hline LMLY 3 & 50 & $196-209$ & 5 & 0.44 & 0.13 \\
\hline LMLY 4 & 50 & 281-304 & 6 & 0.64 & 0.76 \\
\hline LMLY 5 & 50 & $146-159$ & 7 & 0.16 & 0.14 \\
\hline LMLY $6^{1}$ & 50 & $216-240$ & 9 & NA & NA \\
\hline LMLY $7^{1}$ & 50 & $224-230$ & 3 & NA & NA \\
\hline LMLY 8 & 50 & 288-304 & 5 & 0.55 & 0.80 \\
\hline LMLY 9 & 50 & 93-99 & 4 & 0.67 & 0.89 \\
\hline LMLY 10 & 50 & $311-390$ & 7 & NA & NA \\
\hline LMLY 11 & 45 & $155-156$ & 2 & 0.495 & 0.41 \\
\hline LMLY 12 & 45 & 202-209 & 6 & 0.696 & 0.81 \\
\hline
\end{tabular}

and balance of plant growth substances and specific enzymes during embryo development. But it has been reported that weather conditions, especially prevailing temperature regimes after fruit set, can also influence the levels of aborted seeds [22].

'Yook Ho Pow' was best performing in terms of fruit weight $[(21.2 \pm 1.6) \mathrm{g}]$ (table V), percentage of chicken-tongued seeds $[(78.2 \pm 2.5) \%]$ and pulp to seed ratio $(16.1 \pm 3.3)$ (table VT). Its only disadvantage was its green colour, which might not be appealing to consumers.

Despite having a large fruit size, the cultivars 'Bengal' and 'Calcuttia Late' were disadvantaged by their low percentage of chicken-tongued seeds (less than 5\%). It was further observed that these two cultivars had the longest seeds, with lengths exceeding $20 \mathrm{~mm}$ for both chicken-tongued and normal seeds (table VI).

\subsection{Genetic diversity of accessions}

A total of 66 amplification fragments were detected among the 12 SSR loci analysed in the litchi accessions studied (table VII). The number of alleles per locus ranged from 2 (LMLY 11) to 9 (LMLY 6), with an average of 5.5 alleles per locus. This value is similar to the 4.9 alleles per locus found with the same SSR loci in a different germplasm collection [7]. Several dendrograms were possible and the dendrogram with the highest cophenetic correlation between the cophenetic matrix and the similarity matrix (0.90) was chosen (figure 1). The combination of different amplified fragments with 12 pairs of SSR primers gave 14 different profiles. All the litchi genotypes clustered in the same group and the local longan genotype analysed appears as a clear outgroup.

Consistently, cultivars with identical SSR profiles also had similar fruit and leaf characteristics. One case of homonymy was detected with the two 'Casino' accessions (7 and 31), that were found to have different SSR profiles (figure 1). Among the accessions analysed for their SSR profiles, there were two groups with different accession names which could not be distinguished by SSR analysis. The first group is group 5.1 (figure 1) with the accessions 'Heiye', 'Hong Kong' and 'Salathiel'. The second group is group 4.4 with 'Bengal' and 'Calcuttia Late'. Some of these synonymies are unexpected based on the origin of the cultivars and point to mistakes in the naming of the material. Consequently, comparison with germplasm 
maintained in other collections should be made in order to correctly assess the identity of these genotypes. On the other hand, 'Huazhi' and 'Wai Chee' have been reported as synonyms in the literature [23]. However, in our work they can be clearly differentiated with molecular markers, indicating that further work is needed to check the origin of those two genotypes in Mauritius. Such cases of synonymies and homonymies have also been found by other authors [5, 7, 24, 25]. These are attributed to the use of varying names for the same cultivar in different Chinese dialects and increasing confusion in the course of litchi's dissemination to other countries. Hence it is clear that molecular tools are essential and complementary to agronomic traits for proper cultivar identification and optimum germplasm management. All the trees classified under the name 'Tai So' did not show any differences in their SSR profiles with the set of molecular markers used in our work. This commends a more in-depth study of environmental conditions which might have led to higher levels of chicken-tongued seeds and larger leaf sizes in Labourdonnais.

Bootstrap resampling analysis was used as a tool to estimate the validity of the clusters of the dendrogram. Any branch (cluster of cultivars) that appeared more than 1000 times in the 2000 bootstrap replicates could be regarded as substantiated by the analysis. Hence the grouping of accessions 'Bosworth 3' with 'Kwai May Pink' and 'Casino (31)'; 'Casino' (7) with 'Heong Lai'; 'Yuan Zhi' with 'Wai Chee'; 'Calcuttia Late' with 'Bengal' and 'Jensen'; and 'Heiye' with 'Hong Kong' and 'Salathiel' were highly substantiated.

Our paper is the first report of the morphological and molecular diversity of litchi germplasm in Mauritius. The results obtained indicate that agroclimatic differences in the country should be taken into account in order to optimise current litchi production, mainly for the export market. Moreover, the molecular analysis showed no differences among the different 'Tai So' genotypes analysed, but appropriate comparison with other germplasm collections in other countries should be performed in order to ensure the correct identity of the germplasm present in Mauritius.

\section{Acknowledgements}

Financial support for this work was provided by the Spanish Ministry of Education (Project Grant AGL2007-60130/AGR) and the AECI of the Spanish Ministry of Foreign Affairs. The authors acknowledge the support provided by the following institutions in Mauritius for the conduct of this study: the Agricultural Research and Extension Unit, the Food and Agricultural Research Council, and the University of Mauritius. The support of Mr. Krish Googoolye for his advice on statistical analysis of data is acknowledged.

\section{References}

[1] Morton J.F., Fruits of warm climates, Morton J.F., Miami, Florida, USA, 1987.

[2] Huang X., Subhadrabandhu S., Mitra S.K., Ben-Arie R. Stern, R.A., Origin, history, production and processing, in: Menzel C.M., Waite G.K. (Eds.), Litchi and Longan: Botany, Production and Uses, CAB Int., Wallingford, U. K., 2005.

[3] Rouillard G., Guého J., Les plantes et leur histoire à l'île Maurice, Éd. Océan Indien, Rose Hille, Mauritius, 1999.

[4] Anon., Litchi in Mauritius. Production, Processing and Export, Agric. Res. Ext. Unit, Publ. by AREU/FARC, Quatre Bornes, Mauritius, 2002.

[5] Anuntalabhochai R., Chundet R., Chiangda J., Apavatjrut P., Genetic diversity within lychee based on RAPD analysis, Acta Hortic. 575 (2002) 253-259.

[6] Wünsch A., Hormaza J.I., Cultivar identification and genetic fingerprinting of temperate fruit tree species using DNA markers, Euphytica 125 (2002) 59-67.

[7] Viruel M.A, Hormaza J.I., Development, characterization and variability analysis of microsatellites in lychee, Theor. Appl. Genet. 108 (2004) 896-902.

[8] Li M., Zheng X., Zhu Y., Wang X., Liang S., Li L., Wu X., Development and characterisation of SSR markers in lychee (Litchi chinensis), Mol. Ecol. Notes 6 (2006) 1205-1207.

[9] Anon., Descriptors for litchi (Litchi chinensis), Int. Plant Genet. Res. Inst. (IPGRI), Rome, Italy, 2002. 
[10] Nei M., Li W.H., Mathematical-model for studying genetic-variation in terms of restriction endonucleases, Proc. Natl. Acad. Sci. USA 76 (1979) 5269-5273.

[11] Van de Peer Y., De Watchter R., TREECON for Windows: A software package for the construction and drawing of evolutionary trees for the Microsoft Windows environment, Comput. Appl. Biosci. 10 (1994) 569570.

[12] Menzel C.M, Rasmussen T.S., Simpson D.R., Effects of temperature and leaf water stress on growth and flowering of litchi (Litchi chinensis Sonn.), J. Hortic. Sci. 64 (1989) 739-752.

[13] Anupunt P., Sukhvibul N., Lychee and longan production in Thailand, Acta Hortic. 665 (2005) 53-59.

[14] Chen H.B., Huang H.B., Low temperature requirements for floral induction in lychee, Acta Hortic. 665 (2005) 195-202.

[15] Huang H.B., Chen H.B., A phase approach towards floral formation in lychee, Acta Hortic. 665 (2005) 185-194.

[16] Menzel C.M., Simpson D.R., Effects of temperature on growth and flowering of litchi (Litchi chinensis Sonn.) cultivars, J. Hortic. Sci. 63 (1988) 349-360.

[17] O'Hare J.T., Interaction of temperature and vegetative flush maturity influences shoot structure and development of lychee (Litchi chinensis Sonn.), Sci. Hortic. 95 (2002) 203211.

[18] Menzel C.M., Simpson D.R., Effects of temperature and leaf water stress on panicle and flower development of litchi (Litchi chinensis Sonn.), J. Hortic. Sci. 66 (1991) 335-344.

[19] Lu L.X., A review of embryo development in litchi, Acta Hortic. 558 (2001) 241-242.

[20] Chen W., Lu L.X., Endogenous hormones in relation to embryo development in litchi, Acta Hortic. 558 (2001) 247-250.

[21] Menzel C.M., The physiology of growth and cropping in lychee, Acta Hortic. 558 (2001) 175-184.

[22] Huang H.B., Towards a better insight into the development of the arillate fruit of litchi and longan, Acta Hortic. 558 (2001) 185-192.

[23] Menzel C.M., Huang X., Liu C., Cultivars and plant improvement, in: Menzel C.M., Waite G.K. (Eds.), Litchi and longan: botany, production and uses, CAB Int., Wallingford, U. K., 2005.

[24] Aradhya M.K., Zee F.T., Manshardt R.M., Isozyme variation in lychee (Litchi chinensis Sonn), Sci. Hortic. 63 (1995) 21-35.

[25] Degani C., Deng J., Beiles A., El-Batsri R., Goren M., Gazit S., Identifying lychee cultivars and their genetic relationships using Intersimple Sequence Repeat Markers, J. Am. Soc. Hortic. Sci. 128 (2003) 838-845.

\section{Diversidad fenotípica y molecular de los cultivares de lichi de la isla Mauricio.}

Resumen - Introducción. El lichi adquirió una importancia económica en la isla Mauricio, ya que se valora mucho en los mercados locales y de exportación gracias a su tamaño, su color y su sabor. Sin embargo, hasta el momento, no se ha realizado ningún trabajo de caracterización. Material y métodos. Con el fin de optimizar la gestión del material genético del lichi en la isla Mauricio, procedimos antes a la evaluación de 34 accesiones del lichi repartidas en tres regiones agroclimáticas. Se estudiaron los caracteres fenotípicos y morfológicos de los frutos, así como los marcadores microsatélites. Resultados y discusión. Las observaciones fenológicas realizadas en cuatro ciclos de fructificación consecutivos (2003/2004 a 2006/2007) mostraron que las accesiones podrían reagruparse en cultivares de floración precoz o tardía, a partir de panículas florales formadas de junio a julio y de julio a agosto, respectivamente. La temporada de cosecha del lichi duró desde mediados de noviembre hasta mediados de enero, las variedades precoces pudieron cosecharse sin embrago ya desde el primer mes de la campaña. Los rasgos fenológicos y la caracterización de los frutos mostraron que el cultivar introducido recientemente 'Yook Ho Pow' tenía un fuerte potencial comercial. Unos estudios moleculares que emplearon doce pares de cebos de RSS demostraron que, a pesar de las variaciones fenotípicas en los genotipos de 'Tai So' en diversos medios (tales como el porcentaje de semillas 'lengua de pollo' o como el tamaño del foliolo), los perfiles de RSS de las muestras de hojas de todas las accesiones de 'Tai So' estudiados eran idénticos. Esto sugeriría que las diferencias fenotípicas observadas podrían atribuirse a las condiciones medioambientales más que a variaciones genéticas. La caracterización molecular mostró diversos casos de sinonimia y de homonimia en los genotipos estudiados.

Mauritius / Sapindaceae / Litchi chinensis / características agronómicas / microsatélites / fenología / RSS 